\author{
M.Yu. Ishmuratova ${ }^{1}$, M.A. Zhunussova ${ }^{2}$, S.S. Tyrzhanova ${ }^{1}$, M.M. Silant'eva ${ }^{3}$ \\ ${ }^{I}$ Ye.A. Buketov Karaganda State University, Kazakhstan; \\ ${ }^{2}$ Karaganda Medical University, Kazakhstan; \\ ${ }^{3}$ Altai State University, Barnaul \\ (E-mail: margarita.ishmur@mail.ru)
}

\title{
Study of spreading and plant resources of herbs Scabiosa ochroleuca L. and Scabiosa isetensis L. on the territory of Karaganda region
}

\begin{abstract}
The results of the study of the distribution and raw stocks of herbs Scabiosa ochroleuca and Scabiosa isetensis are presented in the article. Populations involving Scabiosa ochroleuca are timed to meadow, stable meadows, scaffolding forests, river valleys, and intersectional downhill. Individuals grow on the territory of the mountains of Karkaraly, Kuu, Ulytau, Ortau, Kyzyltau, Aksoran, Kent, Bektauata, Buyratau, Spasskiy hills, on river valleys of the rivers Nura, Sherubai-Nura, Sarysu, Shiderty, etc. Features of growth of Scabiosa ochroleuca as a part of a cereal-herbal varia Scabiosa ochroleuca, scabiosa-herbal varia, herbal varia-cereal and herbal varia-shrubby community are described. Yield of above-ground was $220-350 \mathrm{~kg} / \mathrm{ha}$ (in terms of air-dry weight). The total area of detected crops with the participation of Scabiosa ochroleuca co-set 61.3 hectares with an exploitation reserve of 186.26 centners, the volume of possible collection of raw materials - 111.76 centners. The growth of Scabiosa isetensis is timed to the slopes and tops of rocky nozzles, slopes of mountains, steppe rae-nine areas. Individuals of this species are found in the mountains of Karkaraly, Ulytau, Ortau, Kyzyltau, in the desert of Beth-pakdala, on the exits of rocks of the Central Kazakhstan small breeder as part of scabiosa-stipa-herbal varia and cereal-herbal varia communities. Yield of air-dry raw materials was $285-310 \mathrm{~kg} / \mathrm{ha}$. The total area is calculated at $29.8 \mathrm{ha}$, exploitation reserve is 87.83 centners, the volume of possible raw material collection is calculated at 52.70 centners.
\end{abstract}

Keywords: Scabiosa ochroleuca, Scabiosa isetensis, spreading, harvest, raw material resources, Central Kazakhstan, population, exploitation reserve, volume of possible collection.

\section{Introduction}

About 6,000 species of vascular plants grow in the Republic [1], about 1000 species have information about the use in folk medicine [2] or proven biological activity [3]. At the same time, the Pharmacopoeia of Kazakhstan includes about 160 species of plants, half of which do not grow in the natural flora. Increasing interest in phytotherapy and phyto-pharmacology in the world $[4,5]$ raises the question of expanding the range of herbs by introduction species of natural flora.

Most interested for the study is objects having sufficient range and stocks suitable for industrial gathering of raw materials.

In recent years, among the objects under study, the genus Scabiosa L. (Dipsacaceae family) has the greatest prospect. The most common species in Kazakshatn are Scabiosa ochroleuca L. and Scabiosa isetensis L. [3], which show a wide range of biological activity: antioxidant, antimicrobial, antiradical, antiinflammatory, cytotoxic, antipyretic, diuretic and others [3, 6-8]. In folk medicine, species of genus Scabiosa L. find applications in the treatment of respiratory diseases (asthma, re-spiral infections, tuberculosis, coughing), rheumatism, gout, gastrointestinal tract, atherosclerosis, rheumatism, bones and for improving blood circulation [2, 3, 8-15]. On the basis of the above-ground organs of both species of Scabiosa, projects of regulatory documentation for raw materials has been proposed, the technology of obtaining extracts and their biological activity have been elaborated [16].

In order to fully assess the feasibility of using species as sources of medicinal raw materials, a study of distribution and raw materials is needed. This aspect was the purpose of this study.

\section{Objects and methodology}

The study focused on natural populations of Scabiosa ochroleuca L. and Scabiosa isetensis L., which grow in the territory of Karaganda region.

Identification of habitats of the species was carried out according to herbal samples of Ye.A. Buketov Karaganda State University, JSC «Scientific and production holding» Phytochemistry», field diaries and results of expeditionary trips. 
In the study of raw materials were applied traditional methodological guidelines [17-19]. Field study of plants was carried out in 2016-2019 by route-reconnaissance method with lying of accounting sites. The number of sites of $1 \mathrm{~m}^{2}$ varied from 30 to 50 pieces. Raw materials were cut from each site and weighed on a wet and air-dry weight. Only well-developed samples in the generative phase were taken into account when assessing stocks.

The average value of weight from the one accounting site was recalculated per unit area, yield data was radiated. Area of areas of both species of Scabiosa was determined by equating sides with a geometric figure, measuring a figure side pedometer and calculating its area. Calculation of explotation reserve was carried out by multiplying plo-slot by yield, volume of possible collection - as $40-45 \%$ of explotation reserve.

Statistical treatment of the results was carried out according to the method of N.L. Udolskaya [20].

\section{Results and discussion}

The study of the distribution of species showed that Scabiosa ochroleuca and Scabiosa isetensis are widespread on the territory of the Central Kazakhstan, forming seedlings suitable for raw materials harvesting.

Populations involving Scabiosa ochroleuca are timed to meadow, steppe meadow areas, forest blades, river valleys, and intervalley downsides. The meeting of plants in the mountains of Karkaraly, Kuu, Ulytau, Ortau, Kyzyltau, Aksoran, Kent, Bektauata, Buyratau, Spassky hills, on the river valleys of Nura River, Sherubai-Nura, Sarysu, Shiderts, etc. (Fig. 1).

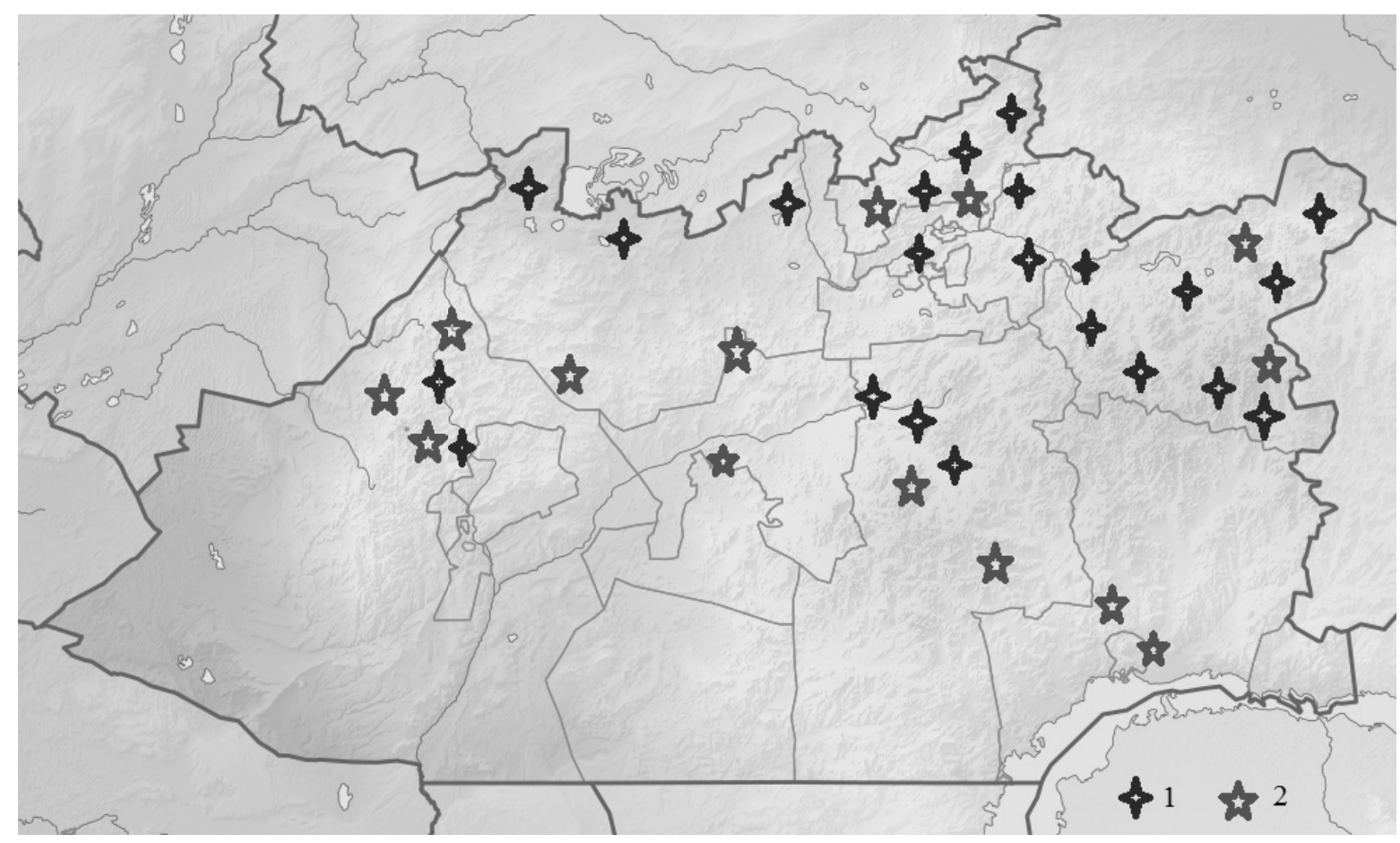

1-Scabiosa ochroleuca; 2 - Scabiosa isetensis

Figure 1. The spreading of populations of Scabiosa ochroleuca and Scabiosa isetensis on the territory of the Karaganda region

Scabiosa isetensis is a more xerophytic species, whose populations are located to the slopes and tops of rocky nozzles, on the slopes of mountains, on steppe lowland areas. It is found in the mountains of Karkarala, Ulytau, Ortau, Kyzyltau, in the Betpakdala Desert, on the exits of the rocks of the centralkazakhstany hills.

Thickets of Scabiosa ochroleuca are noted in the territory of the Korneevsky woods, in Mountains Ulytau, Spassky hills and in Mountains Buyratau, being a part cereal — herbal varia, scabiosa — herbal varia, herbal varia - cereal and herbal varia - shrubby communities. 


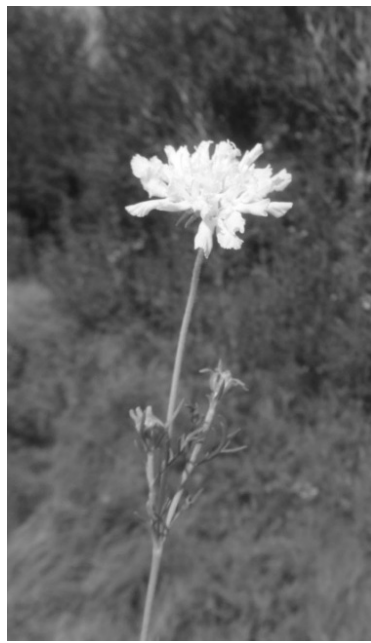

Figure 2. Flowering shoot of Scabiosa ochroleuca in Korneevsky woods
In the cereal - herbal varia community in Korneev forests (BukharZhyrau district of Karaganda region) the total projective coating was 80 $85 \%$, the aspect of vegetation was motley-green. In the community Calamagrosis epigeios dominated with an abundance of cop1 and a vitality of 4-5 points, the subdominant was Scabiosa ochroleuca with an abundance of sp and a vitality of 5 points (Fig. 2).

The species composition of the community is estimated by 20-25 species with an abundance of sol-sp and a vitality of 3 to 5 points. Plants are placed in 2 tiers: the upper ( $80-100 \mathrm{~cm}$ high) is represented by high-growth herbs Calamagrostis epigeios, Achillea salicifolia, Artemisia dracunculus, Scabiosa ochroleuca, Serratula cotonata; the lower tier (20 to $70 \mathrm{~cm}$ high) is represented by low-growth herbaceous species Vicia cracca, Lathyrus pratensis, Trifolium lupinaster and others.

The yield of above-ground parts of Scabiosa ochroleuca was $250 \mathrm{~kg}$ of dry raw material per 1 ha (Table 1 ).

The area of the overgrowth is estimated at 12.5 hectares. The exploitation reserve was 31.25 centners, and the volume of possible collection 18.75 centners.

$\mathrm{T}$ a b $1 \mathrm{e} 1$

Yield and raw material resources of Scabiosa ochroleuca in the territory of the Central Kazakhstan

\begin{tabular}{|l|c|c|c|c|c|}
\hline \multicolumn{1}{|c|}{ Community } & Place of location & $\begin{array}{c}\text { Yield, } \\
\mathrm{kg} / \mathrm{ha}\end{array}$ & Square, ha & $\begin{array}{c}\text { Exploitation } \\
\text { reserve, centner }\end{array}$ & $\begin{array}{c}\text { Volume of possible } \\
\text { collection, centner }\end{array}$ \\
\hline Cereal - herbal varia & Korneevsky woods & $250 \pm 5$ & 12,5 & 31,25 & 18,75 \\
\hline Scabiosa - herbal varia & Ulytau Mountains & $312 \pm 11$ & 22,4 & 69,89 & 41,93 \\
\hline Herbal varia - cereal & Spassky hills & $220 \pm 12$ & 5,6 & 12,32 & 7,40 \\
\hline $\begin{array}{l}\text { Herbal varia - shrubby } \\
\text { communities }\end{array}$ & Buyratau Mountains & $350 \pm 15$ & 20,8 & 72,80 & 43,68 \\
\hline TOTAL: & & 61,3 & 186,26 & 111,76 \\
\hline
\end{tabular}

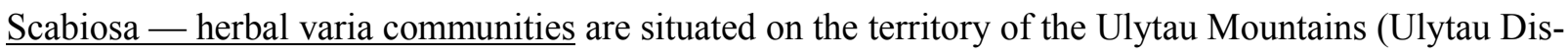
trict of Karaganda Region), live on the sub-mountain plains with settled meadows. The general projective community coverage is $95-100 \%$. The aspect is green with yellow spots. The dominated species in the community was Scabiosa ochroleuca with an abundance of cop1 and a vitality of 5 points, the remaining species are components with an abundance of sol-sp and a vitality of 4-5 points. Species composition is estimated in 25-27 species. The species are placed in 2 tiers: the upper one (up to $90 \mathrm{~cm}$ high) consists of highedged herbs as Filipendula ulmaria, Scabiosa ochroleuca, Calamagrostis epigeios; lower tier (up to $40 \mathrm{~cm}$ high) form such species as Galatella angustifolia, Achillea millefolium, Glycyrrhiza uralensis and others.

The total volume of communities was 22.4 ha with an average yield of $312 \mathrm{~kg} / \mathrm{ha}$ of air-dry raw materials (Table 1). The exploitation reserve of raw materials of above-ground parts amounted to 69.89 centners with the volume of possible collection - 41.93 centners.

Herbal varia-cereal community is situated in Spassky hills (Bukhar-Zhyrau district of Karaganda region), located on inter-river and river valleys. The total projective cover was $75-80 \%$, the aspect was motly. Dominant in the community was Filipendula ulmaria with abundance of cop-sp and a vitality 4 points, codominants are Agropyron cristatum, Hordeum jubatum with abundance of sp and vitality 3-4 points. The rest species of the community (23-25 species) is composed as components with an abundance of un-sol-sp and a vitality of 3-5 points. The plant is placed in 2 tiers - upper and lower herbaceous. The upper tier $(60-80 \mathrm{~cm}$ high) is formed by Filipendula ulmaria, Tanacetum vulgare, Scabiosa ochroleuca, Calamagrostis epigeios; lower (up to $30 \mathrm{~cm}$ high) consists of individuals Galatella divaricata, Sanguisorba officinalis, Trifolium arvense, etc.

The yield of Scabiosa ochroleuca was $220 \mathrm{~kg} / \mathrm{ha}$. The total area of communities involving Scabiosa was 5.6 hectares. The explotaition reserve was 12.32 centners and the volume of possible collection was 7.40 centners.

Herbal varia - shrub communities have been identified on the territory of the Buyratau Mountains (Osakarov district of Karaganda region) on lowland and foothills areas on an area of 20.8 hectares. Total pro- 
jective cover was 80-90\%, aspect of motly-green. Dominant in the community was Spiraea hypericifolia with an abundance of sp and a vitality of 4 points; co-dominant was Galatella tatarica with an abundance of sp and a vitality of 3-4 points. The component composition of communities is defined in 20-22 species. In this community, species grow in 3 tiers. The upper shrub tier $(100-120 \mathrm{~cm}$ tall) is formed by individuals of Spiraea hypericifolia; the middle tier (50-100 cm high) formed with high-growth herbs - Scabiosa ochroleuca, Calamagrostis epigeios, Alopecurus pratense, Kochia scoparia; the third tier (up to $50 \mathrm{~cm}$ tall) formed low herbs - Galatella tatarica, Agropyron cristatum, Lathyrus pratensis, Allium rubens and others.

The yield at this point was a maximum of $350 \mathrm{~kg} / \mathrm{ha}$ (Table 1). The explotation reserve amounted to 72.80 centners, and the volume of possible collection was 43.68 centners.

Thus, the total area of detected communities with the participation of Scabiosa ochroleuca is amounted to 61.3 hectares with an exploitation reserve of 186.26 centners, the volume of possible collection of raw materials -111.76 centners.

For Scabiosa isetensis significant overgrowth is noted in the mountains of Ulytau and Buyratau on the dry rocky areas and slopes of hills (Fig. 3). Sometimes the growth sites of both species can intersect.

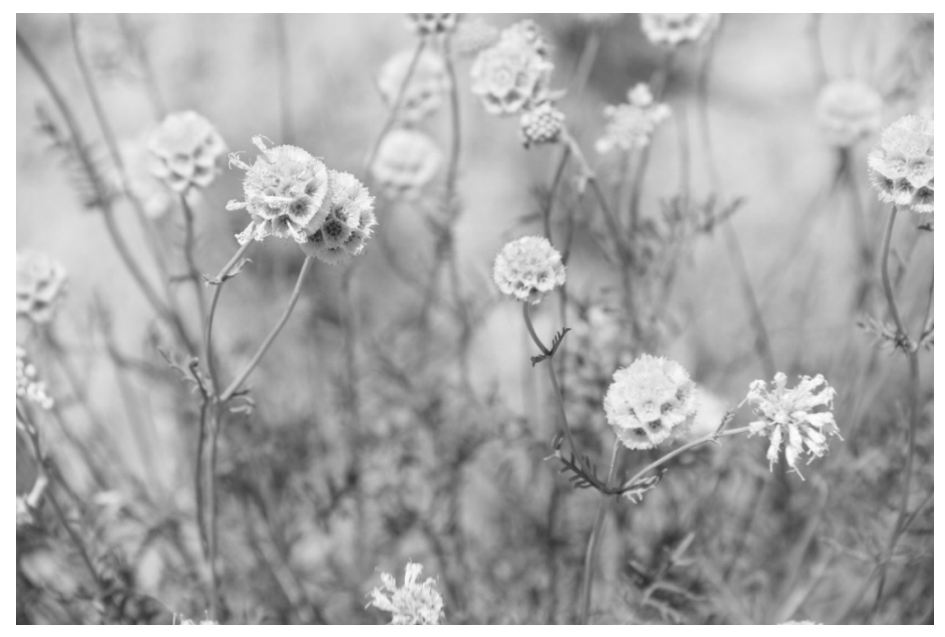

Figure 3. Flowering shoot of Scabiosa isetensis in Ulytau Mountains

In nature were noted scabiosa - festuca - herval varia and cereal - herbal varia communities with participation of Scabiosa isetensis.

Scabiosa - festuca - herval varia communities are situated to the slopes of the low scrolls and the foot of the Ulytau Mountains, mainly the southern and eastern exposition. Total projective cover ranged from 60 to $75 \%$, species composition was 18-20 species, vegetation aspect pale-green with motly inclusions.

In the community on the territory of the Ulytau mountains is dominated Festuca valesiaca with an abundance of cop 1 and a vitality 3-4 points, co-dominant was Scabiosa isetensis with an abundance sp and a vitality 4 points. Community components have an abundance of un to sol and a vitality of 2-5 points. Due to the sparse growth of plants, no tiers have been isolated.

The area was estimated at 18.2 ha with a yield of $285 \mathrm{~kg} /$ ha of air-dry raw material (Table 2). The exploitation stock of raw materials is defined as 51.87 centners with the volume of possible raw materials collection of 31.12 centners.

Table 2

Yield and raw material resources of Scabiosa isetensis in the territory of the Central Kazakhstan

\begin{tabular}{|l|c|c|c|c|c|}
\hline \multicolumn{1}{|c|}{ Community } & Place of location & $\begin{array}{c}\text { Yield, } \\
\mathrm{kg} / \mathrm{ha}\end{array}$ & $\begin{array}{c}\text { Square, } \\
\text { ha }\end{array}$ & $\begin{array}{c}\text { Exploitation } \\
\text { reserve, centner }\end{array}$ & $\begin{array}{c}\text { Volume of possible } \\
\text { collection, centner }\end{array}$ \\
\hline Scabiosa - festuca - herval varia & Ulytau Mountains & $285 \pm 12$ & 18,2 & 51,87 & 31,12 \\
\hline Cereal - herbal varia & Buyratau Mountains & $310 \pm 15$ & 11,6 & 35,96 & 21,58 \\
\hline TOTAL: & & 29,8 & 87,83 & 52,70 \\
\hline
\end{tabular}

In the Buyratau Mountains Scabiosa isetensis lives as part of a cereal-herbal varia community. The total projective cover is 50-60\%, the vegetation aspect is motly. Individuals of Scabiosa are located to slopes of 
nozzles and lowland steppe sections. In this community is dominated Stipa pennata and Agropyron cristatum with an abundance of cop1-2 and a vitality of 5 points, co-dominant was Scabiosa isetensis with an abundance of sp-cop and a vitality of 3-4 points. The remaining species 20-22 are classified as components with an abundance of un-sol-sp and a vitality of 3-5 points.

The yield of the raw material was $310 \mathrm{~kg} / \mathrm{ha}$; the exploitation reserve was estimated at 35.96 centners at the volume of possible raw material collection of 21.58 centners (Table 2).

The total area of Scabiosa isetensis is calculated at 29.8 ha, exploitation reserve is 87.83 centners, the volume of possible raw material collection is calculated at 52.70 centners.

\section{Conclusion}

On the territory of the Central Kazakhstan (Karaganda region) the main places of location and points of growth of Scabiosa ochroleuca and Scabiosa isetensis have been revealed. Populations with the participations of Scabiosa ocroleuca are located to meadow, steppe meadow areas, woods edges, river valleys, lowhill depressions. The occurrence of the plant in the mountains of Karkaraly, Kuu, Ulytau, Ortau, Kyzyltau, Aksoran, Kent, Bektauata, Buyratau, Spassky hills, on the river valleys of Nura River, SherubaiNura, Sarysu, Shiderty, etc.

Thickets of Scabiosa ochroleuca are noted on the territory of the Korneevsky woods, in Mountains Ulytau, Spasky hills and in Mountains Buyratau, being a part cereal - herbal varia, scabiosa - herbal varia, herbal varia - cereal and herbal varia - shrubby communities. The total area of Scabiosa ochroleuca was 61.3 hectares with an exploitation reserve of 186.26 centners, the volume of possible collection of raw materials - 111.76 centners.

Scabiosa isetensis is a more xerophytic species, whose populations are located to the slopes and tops of rocky nozzles, on the slopes of mountains, on steppe lowland areas. It is found in the mountains of Karkraly, Ulytau, Ortau, Kyzyltau, in the Betpakdala Desert, on the exits of the rocks of the central-kazakhstany hills as a part of scabiosa - festuca - herval varia and and cereal - herval varia communities. The total area of Scabiosa isetensis was 87.83 centners, and the volume of possible raw material collection is calculated at 52.70 centners.

\section{References}

1 Абдулина С.А. Список сосудистых растений Казахстана / С.А. Абдулина. - Алматы, 1998. - 187 с.

2 Грудзинская Л.М. Аннотированный список лекарственных растений Казахстана: справоч. изд. / Л.М. Грудзинская, Н.Г. Гемеджиева, Н.В. Нелина, Ж.Ж. Каржаубекова. - Алматы, 2014. - 200 с.

3 Растительные ресурсы СССР: Цветковые растения, их химический состав, использование. - Л.: Наука, $1982-1995$.

4 Compendiums of Medicinal and Aromatic Plants. Vol. II. Asia. - Triestre: ICS-UNIDO, 2006. - 305 p.

5 Kong J.M. Recent advances in traditional plant drugs and orchids / J.M. Kong, N.K. Goh, L.S. Chia, T.F. Chia // Acta Pharmacologica Sinica. - 2003. - Vol. 24. - P. 7-21.

6 Javidnia K. Constituents of the essential oil of Scabiosa flavida from Iran / K. Javidnia, R. Miri, A. Javidnia // Chemistry of Natural Compounds, 2006. - Vol. 42, Iss. 5. — P. 529, 530.

7 Крупенникова В.Г. Фенолкарбоновые кислоты скабиозы венечной и скабиозы бледно-желтой / В.Г. Крупенникова, Г.М. Федосеева // Сиб. мед. журн. — 2007. — № 4. — С. 90-92.

8 Kukuła J. Medicinal plants of the dipsacaceae / J. Kukuła, E. Witkowska-Banaszczak // Postępyfitoterapii. — 2014. — No. 4. - P. 232-238.

9 Christopoulou C. Chemosystematic value of chemical constituents from Scabiosa hymettia (Dipsacaceae) / C. Christopoulou, K. Graikou, I. Chinou // Chemistry \& Biodiversity, 2008. - Vol. 5. — P. 318-323.

10 Hlila M.B. $\alpha$-Glucosidase inhibition by Tunisian Scabiosa arenaria Forssk. extracts / M.B. Hlila, H. Mosbah, K. Majouli // International Journal of Biological Macromolecules. — 2015. — No. 77. — P. 383-389.

11 Zheng Q. New biologically active triterpenoid saponins from Scabiosa tschiliensis / Q. Zheng, K. Koike, H. Li-Kun, H. Okuda, T. Nikaido // J. Nat. Prod. - 2004. - No. 67 (4). - P. 604-613.

12 Hlila M.B. Acetylcholinesterase inhibitory and antioxidant properties of roots extracts from the Tunisian Scabiosa arenaria Forssk. / M.B. Hlila, H. Mosbah, K. Mssada // Industrial Crops and Products. — 2015. — Vol. 67. — P. 62-69.

13 Жунусова M.A. Способ получения $\mathrm{CO}_{2}$-экстракта из Scabosa ochroleuca (L.), обладающего противомикробной активностью / М.А. Жунусова, М.Ю. Ишмуратова, Р.М. Абдуллабекова // Патент на изобретение № 33430 от 01.02.2019.

14 Жунусова M.А. Способ получения $\mathrm{CO}_{2}$-экстракта из Scabosa isetensis (L.), обладающего цитотоксической активностью / М.А. Жунусова, М.Ю. Ишмуратова, Р.М. Абдуллабекова // Патент на изобретение № 33431 от 01.02.2019.

15 Kowalczyk A. Preliminary antifungal activity of some Dipsacaceae family plants / A. Kowalczyk, J. Krzyzanowska // Herba Polonica. - 1999. - Vol. 45, No. 2. - P. 101-107. 
16 Жунусова М.А. Фармацевтическая разработка лекарственных средств из растительного сырья Scabiosa ochroleuca L. и Scabiosa isetensis L.: дис. ... PhD. 6D074800 - «Технология фармацевтического производства» / М.А. Жунусова. Караганда, 2019. - 175 с.

17 Понятовская В.М. Учет обилия и характера размещения растений в сообществах / В.М. Понятовская // Тр. БИН. Сер. III. Геоботаника. - М.; Л., 1964. - Вып. 3. - С. 209-299.

18 Крылова И.Л. Методика ориентировочной оценки величины запасов лекарственного растительного сырья / И.Л. Крылова, В.И. Капорова, Л.С. Соболева, Т.М. Киселева // Раст. ресурсы. — 1989. — Т. 25, № 3. — С. $426-432$.

19 Крылова И.Л. Методические указания по изучению запасов дикорастущих лекарственных растений / И.Л. Крылова, А.И. Шретер. - М.: ВИЛАР, 1971. - $31 \mathrm{c.}$

20 Удольская Н.Л. Введение в биометрию / Н.Л. Удольская. — Алма-Ата: Изд-во КазГУ, 1978. — 248 с.

\title{
М.Ю. Ишмуратова, М.А. Жунусова, С.С. Тыржанова, М.М. Силантьева
}

\section{Scabiosa ochroleuca L. және Scabiosa isetensis L. дәрілік өсімдіктерінің Қарағанды облысы аумағында таралуы мен өсімдік ресурстарын зерттеу}

\begin{abstract}
Мақалада дәрілік өсімдіктердің — Scabiosa ochroleuca мен Scabiosa isetensis-дың таралуы мен шикізат қорын зерттеу нәтижелері келтірілген. Бозғылт сары скабиоздың популяцияларына шалғындық, дала шалғындары, орман жиектері, өзен аңғарлары жатады. Дарақтар Қарқаралы, Қу, Ұлытау, Ортау, Қызылтау, Ақсораң, Кент, Бектауата, Бұйратау тауларында, Спасск қыраттарында, Нұра, ШерубайНұра, Сарысу, Шідерті және т.б. өзен аңғарларында өседі. Дәнді-шөпті, скабиозды-шөпті, шөпті-дәнді және шөпті бұталар тобының құрамындағы бозғылт сары скабиоздың өсу ерекшеліктері сипатталған. Бозғылт-сары скабиоздың жер бетіндегі өнімділігі 220-350 кг/га құрады (ауадағы құрғақ салмағы бойынша). Бозғылт сары скабиоздың қатысуымен анықталған қотырлардың жалпы ауданы 61,3 га, пайдалану резерві 186,26 ц, ал мүмкін болатын шикізатты жинау көлемі - 111,76 ц құрады. Изетикалық скабиоз таулы қыраттарда, тау бөктерлерінде және дала жазықтарының беткейлері мен шыңдарында өседі. Бұл түрдің жеке түрлері Қарқаралы, Ұлытау, Ортау, Қызылтау тауларында, Бетпақдала шөлінде, Орталық Қазақстан ұсақ шоқыларының жартастарында, скабиозды-бетегелішөпті және дәнді-шөпті қауымдастықтардың құрамында кездеседі. Ауамен кептірілген шикізат өнімділігі 285-310 кг/га құрады. Бұталардың жалпы ауданы 29,8 га деңгейінде есептелген, пайдалану қоры 87,83 ц, шикізатты жинау мүмкіндігі 52,70 ц құрады.
\end{abstract}

Кілт сөздер: Scabiosa isetensis, Scabiosa ochroleuca, таралуы, өнімділігі, шикізат қоры, Орталық Қазақстан, популяция, пайдалану қоры, жинаудың мүмкін мөлшері.

\section{М.Ю. Ишмуратова, М.А. Жунусова, С.С. Тыржанова, М.М. Силантьева}

\section{Изучение распространения и растительных ресурсов лекарственных растений Scabiosa ochroleuca L. и Scabiosa isetensis L. на территории Карагандинской области}

В статье приведены итоги изучения распространения и сырьевых запасов лекарственных растений скабиозы бледно-желтой и скабиозы исетской. Популяции с участием скабиозы бледно-желтой приурочены к луговым, остепненным лугам, опушкам лесов, речным долинам, межсопочным понижениям. Особи произрастают на территории гор Каркаралы, Куу, Улытау, Ортау, Кызылтау, Аксоран, Кент, Бектауата, Буйратау, Спасских сопок, по речным долинам рр. Нура, Шерубай-Нура, Сарысу, Шидерты и др. Описаны особенности произрастания скабиозы бледно-желтой в составе злаковоразнотравного, скабиозово-разнотравного, разнотравно-злакового и разнотравно-кустарникового сообщества. Урожайность надземных органов скабиозы бледно-желтой составила 220-350 кг/га (в пересчете на воздушно-сухой вес). Общая площадь выявленных зарослей с участием скабиозы бледножелтой составила 61,3 га при эксплуатационном запасе 186,26 ц, объем возможного сбора сырья 111,76 ц. Произрастание скабиозы исетской приурочено к склонам и вершинам каменистых сопок, склонам гор, к степных равнинным участкам. Особи данного вида встречаются в горах Каркаралы, Улытау, Ортау, Кызылтау, в пустыне Бетпакдала, по выходам скал Центрально-Казахстанского мелкосопочника в составе скабиозово-типчаково-разнотравных и злаково-разнотравных сообществ. Урожайность воздушно-сухого сырья составила 285-310 кг/га. Совокупная площадь зарослей рассчитана на уровне 29,8 га, запас эксплуатации составляет 87,83 ц, объем возможного сбора сырья - 52,70 ц.

Ключевые слова: Scabiosa isetensis, Scabiosa ochroleuca, распространение, урожайность, сырьевые запасы, Центральный Казахстан, популяция, эксплуатационный запас, объем возможного сбора. 


\section{References}

1 Abdulina, S.A. (1998). Spisok sosudistykh rastenii Kazakhstana [The list of vascular plants of Kazakhstan]. Almaty [in Russian].

2 Grudzinskaya, L.M., Gemedzhieva, N.G., Nelina, N.V. \& Karzhaubekova, Zh.Zh. (2014). Annotirovannyi spisok lekarstvennykh rastenii Kazakhstana [Annotative list of herbs of Kazakhstan]. Almaty [in Russian].

3 Rastitelnye resursy SSSR: Tsvetkovye rasteniia, ikh khimicheskii sostav, ispolzovanie [Plant resources of USSR: Vascular Plants, their chemical composition and using]. Leningrad: Nauka, 1982-1995 [in Russian].

4 Compendiums of Medicinal and Aromatic Plants. (Vol. II. Asia). (2006). Triestre.

5 Kong, J.M., Goh, N.K., Chia, L.S. \& Chia, T.F. (2003). Recent advances in traditional plant drugs and orchids. Acta Pharmacologica sinica, 24, 7-21.

6 Javidnia, K., Miri, R., Javidnia, A. (2006). Constituents of the essential oil of Scabiosa flavida from Iran. Chemistry of Natural Compounds, 42, 5, 529-530.

7 Krupennikova, V.G., \& Fedoseeva, G.M. (2007). Fenolkarbonovye kisloty skabiozy venechnoi i skabiozy bledno-zheltoi [Phenolcarbon acids of Scabiosa comosa and Scabiosa ochroleuca]. Sibirskii meditsinskii zhurnal - Siberian Medical Journal, 4, 90-92 [in Russian].

8 Kukula, J. \& Witkowska-Banaszczak, E. (2014). Medicinal plants of the dipsacaceae. Postepyfitoterapii, 4, $232-238$.

9 Christopoulou, C., Graikou, K. \& Chinou, I. (2008). Chemosystematic value of chemical constituents from Scabiosa hymettia (Dipsacaceae). Chemistry \& Biodiversity, 5, 318-323.

10 Hlila, M.B., Mosbah, H., \& Majouli, K. (2015). $\alpha$-Glucosidase inhibition by Tunisian Scabiosa arenaria Forssk. Extracts. International Journal of Biological Macromolecules, 77, 383-389.

11 Zheng, Q., Koike, K., Li-Kun, H., Okuda, H., \& Nikaido, T. (2004). New biologically active triterpenoid saponins from Scabiosa tschiliensis. J. Nat. Prod., 67, 4, 604-613.

12 Hlila, M.B., Mosbah, H., \& Mssada, K. (2015). Acetylcholinesterase inhibitory and antioxidant properties of roots extracts from the Tunisian Scabiosa arenaria Forssk. Industrial Crops and Products, 67, 62-69.

13 Zhunissova, M.A., Ishmuratova, M.Yu., \& Abdullabekova, R.M. (2019). Sposob polucheniia $\mathrm{CO}_{2}$-ekstrakta iz Scabosa ochroleuca (L.), obladaiushcheho protivomikrobnoi aktivnostiu [Method for producing $\mathrm{CO}_{2}$ extract from Scabosa ochroleuca (L.), which has antimicrobial activity]. Patent for the invention No. 33430 from 01.02.2019 [in Russian].

14 Zhunissova, M.A., Ishmuratova, M.Yu., \& Abdullabekova, R.M. (2019). Sposob polucheniia $\mathrm{CO}_{2}$-ekstrakta iz Scabosa isetensis (L.), obladaiushcheho tsitotoksicheskoi aktivnostiu [Method for producing $\mathrm{CO}_{2}$ extract from Scabosa isetensis (L.), which has cytotoxic activity]. Patent for the invention No. 33431 from 01.02.2019 [in Russian].

15 Kowalczyk, A., \& Krzyzanowska, J. (1999). Preliminary antifungal activity of some Dipsacaceae family plants. Herba Polonica, 45, 2, 101-107.

16 Zhunussova, M.A. (2019). Farmatsevticheskaia razrabotka lekarstvennykh sredstv iz rastitelnoho syria Scabiosa ochroleuca L. i Scabiosa isetensis L. [Pharmaceutical development of medical preparation on the base of plant raw materials of Scabiosa ochroleuca L. and Scabiosa isetensis L.]. PhD's thesis. Karaganda [in Russian].

17 Ponyatovskaya, V.M. (1964). Uchet obiliia i kharaktera razmeshcheniia rastenii v soobshchestvakh [Accounting for the abundance and nature of plant placement in communities]. Trudy Instituta botaniki. Seriia III. Heobotanika - Works of Botanical Institute. Series III. Geobotany, Moscow; Leningrad, 3, 209-299 [in Russian].

18 Krylova, I.L., Kaporova, V.I., Soboleva, L.S., \& Kiseleva, T.M. (1989). Metodika orientirovochnoi otsenki velichiny zapasov lekarstvennoho rastitelnoho syria [The method of approximate estimation of the size of stocks of medicinal plant raw materials]. Rastitelnye resursy - Plant resources, 25, 3, 426-432 [in Russian].

19 Krylova, I.L., \& Shreter, A.I. (1971). Metodicheskie ukazaniia po izucheniiu zapasov dikorastushchikh lekarstvennykh rastenii [Guidelines for the study of stocks of wild medicinal plants]. Moscow: All-Russian Institute of Medical and Aromatic Plants [in Russian].

20 Udolskaya, N.L. (1978). Vvedenie v biometriiu [Introduction into biometry]. Alma-Ata [in Russian]. 